\title{
Urdimento
}

Revista de Estudos em Artes Cênicas E-ISSN: 2358.6958

\section{[celas] e elas}

Daiane Dordete

\section{Para citar este artigo:}

DORDETE, Daiane. [celas] e elas. Urdimento,

Florianópolis, v. 3, n. 39, nov./dez. 2020.

DOI: http:/dx.doi.org/10.5965/14145731033920200603 
[celas] e elas ${ }^{1}$

Daiane Dordete ${ }^{2}$

\title{
Resumo
}

Esta peça fricciona relatos de mulheres em situação de cárcere, dados e reflexões sobre processos de privação de liberdade e ressocialização no Brasil e uma dramaturgia original sobre mulheres e opressões sociais. A peça [celas] estreou em sua primeira versão em 2011, realizou diversas apresentações até 2015, e se (des)montou a partir das experiências proporcionadas pelo projeto Teatro com mulheres em privação de liberdade, realizado em 2019 com mulheres do Presídio Regional de Joinville-SC.

Palavras-chave: Celas e elas. Dramaturgia. Mulheres. Teatro feminista. Teatro em prisões.

\section{[cells] and them}

\begin{abstract}
The play [cells] and them was created through the process of theatrical devising and performative lectures. It mixes the testimonials of incarcerated women, statistics and reflections about carceral processes and reentry in Brazil, along with an original script about women and social oppression. The play [cells] debuted in 2011 and had many performances until 2015. It was devised anew using experiences provided by the Theatre with Incarcerated Women program, founded in 2019 by Daiane Dordete and Samira Sinara with women of Presídio Regional de Joinville-SC. The project was made possible by Edital de Apoio à Cultura 2016, supported by Sistema de Desenvolvimento pela Cultura of Joinville-SC.
\end{abstract}

Keywords: Celas e elas. Dramaturgy. Women. Feminist theatre. Theatre in prisions.

\footnotetext{
${ }^{1}$ Estreia realizada em julho de 2019, no SESC Joinville-SC. Direção e dramaturgia: Daiane Dordete. Atuação: Samira Sinara. Músicas: Cleiton Jacobs. Cenário, figurinos e objetos de cena: Daiane Dordete e Samira Sinara. Operação de mídias e contrarregragem: Jackson Silva. Cenotécnica: Cleiton Jacobs e Daiane Dordete. Costura: Dida Dordete. Fotografia: Jessica Michels. Filmagem: Fabrício e Fábio Porto, Tom Dias Gonçalves e Marcelo da Silva. Cessão de pesquisas históricas: Camila Diane Silva. Arte Gráfica: Núcleo de Comunicação da UDESC-CEART. Patrocínio: SIMDEC - Sistema de Desenvolvimento pela Cultura, SECULT - Secretaria de Cultura e Turismo, Prefeitura de Joinville. Apoio: Espaço Cultural Casa Iririú, SESC Joinville e UDESC-CEART. Realização e produção: Cia. vAi! - núcleo de pesquisa em artes cênicas. Classificação indicativa: acima de 16 anos. Duração: 50min.

2 Professora Associada do Departamento de Artes Cênicas da UDESC - Universidade do Estado de Santa Catarina, na área de voz/interpretação, e do Programa de Pós-graduação em Teatro da UDESC. Diretora de Extensão, Cultura e Comunidade do Centro de Artes da UDESC. Doutora e Mestra em Teatro pela UDESC. Bacharela em Artes Cênicas com habilitação em Interpretação Teatral pela FAP - Faculdade de Artes do Paraná (UNESPAR). É atriz, diretora, dramaturga, contadora de histórias e poeta. Pesquisa nas áreas de voz, atuação, performance, teatro performativo, teatro narrativo, teatro feminista, teoria crítica feminista e estudos de gênero.
} 
[celdas] y ellas

\section{Resumen}

Esta dramaturgia mezcla relatos de mujeres en prisión, datos y reflexiones sobre procesos de privación de libertad y resocialización en Brasil, y una dramaturgia sobre las mujeres y la opresión social. La pieza [celdas] debutó en su primera versión en 2011, realizó varias presentaciones hasta 2015, y fue (des)montada a partir de las experiencias del proyecto Teatro con mujeres en privación de libertad, realizado en 2019 con mujeres de la Prisión Regional de Joinville-SC.

Palabras clave: Celas e elas. Dramaturgia. Mujeres. Teatro feminista. Teatro en las cárceles. 


\section{Apresentação}

Esta dramaturgia foi construída durante o processo de criação da (des)montagem teatral e perfopalestra [celas] e elas, que fricciona relatos de mulheres em situação de cárcere, dados e reflexões sobre processos de privação de liberdade e ressocialização no Brasil, e uma dramaturgia original sobre mulheres e opressões sociais.

A peça [celas] estreou em sua primeira versão em 2011, realizou diversas apresentações até 2015, e se (des)montou a partir das experiências proporcionadas pelo projeto Teatro com mulheres em privação de liberdade, realizado em 2019 por Daiane Dordete e Samira Sinara com mulheres do Presídio Regional de Joinville-SC.

O projeto foi viabilizado pelo Edital de Apoio à Cultura de 2016, promovido pelo Sistema de Desenvolvimento pela Cultura de Joinville-SC 
[celas] e elas

\section{Personagens}

As personagens são a própria atriz da peça, Samira Sinara, que interage inicialmente com a diretora e dramaturga da peça, Daiane Dordete. Também há a participação, no prólogo e em outros momentos pontuais de cenas e transições, do operador de mídias, Jackson Silva, e/ou do músico, Cleiton Jacobs.

\section{Prólogo}

(Recepção do público no foyer do teatro/ espaço cênico. Diretora e operador de mídias trajando roupas pretas e coturnos - revistam pessoas; recolhem celulares; colocam crachás de "visitantes", pedem ordem na entrada. Público entra no espaço cênico)

\section{Despertar}

(Samira já está em cena, realizando partitura de despertar, compondo um ambiente que remete a um sonho, a uma outra realidade. Daiane entra, acende uma luminária que está em cena. A música é desligada ao mesmo tempo em que a luz toma conta do espaço, revelando um quadrado delimitado no chão com fita demarca solo, dentro do qual está a atriz. A atriz suspende a partitura física)

Daiane - Abaixa a cabeça e levanta as mãos, não é hora de baixar as mãos ainda!

Samira - Sim, senhora!

Samira - Nossa, quanta gente no xis hoje. Tinha esquecido que era dia de visita. Não reparem a bagunça, vou me arrumar bem rapidinho, tá?!. Alguém trouxe alguma coisa pra gente comer? Chocoleite? Bolo? Da próxima vez, lembrem que não pode trazer coca-cola e fanta uva. Eu só descobri isso esse ano, quando comecei a dar aula de teatro para as mulheres do Presídio Regional de Joinville, junto com a Daiane, que tá ali... Diz oi Daiane. As aulas aconteceram durante todo o primeiro semestre de 2019 e junto com as aulas nós começamos a reensaiar a peça [celas], que havíamos montado em 2011. Daiane, pode contar um pouquinho dessa história, que eu preciso terminar de escovar os dentes?

Daiane - Tá bem, Sá. Bom, para construir o [celas], em 2011, a gente partiu de duas pesquisas de história oral realizadas por Camila Diane Silva. Na primeira, em 2007, a Camila entrevistou mulheres em situação de cárcere no Presídio Regional de Joinville. E na segunda, em 2009, ela entrevistou egressas do sistema carcerário de Joinville. Naquele momento, estávamos interessadas em perceber paradigmas sociais recorrentes nas histórias dessas mulheres, problemáticas que tanto tinham 
levado elas a cometerem crimes quanto a reincidirem nos crimes, por dificuldades encontradas no processo de ressocialização.

Samira - Nessa investigação, nos vimos mergulhadas em muitos desses paradigmas sociais, encurraladas em problemáticas semelhantes às dessas mulheres...

Daiane - e por isso decidimos não representar apenas as histórias dessas mulheres, e sim de muitas mulheres que sofrem repetidas opressões sociais e violências de gênero em nossa sociedade machista.

Samira - mas com as aulas de teatro na prisão, percebemos que talvez a gente nunca sofra com algumas problemáticas e alguns paradigmas sociais que essas mulheres enfrentam. Somos mulheres brancas, de classe média, cisgênero, heterossexuais, que não estão confinadas em uma cela superlotada

Daiane - não fomos abandonadas por nossas famílias e companheiros, não ficamos trancadas 22 horas por dia...

Samira - nós ainda temos acesso à educação pública e gratuita, à arte e à cultura...nós ainda podemos fazer teatro...

Daiane - e por podermos fazer tudo isso é que resolvemos desmontar a peça [celas], e encontrar nela algumas brechas para que as histórias dessas mulheres também possam ser contadas. E ouvidas.

Samira - e lembradas.

Daiane - Sá, vamos começar então?

Samira - vamos.

Tarefas do dia

(Samira cantarola e limpa a cela)

Esta é a mulher que nunca para, que mata 99\% dos germes da sua casa, que leva os cachorros pra passear, que esconde o cocô do neném pro papai não ter que cheirar, que extingue 09 em cada 10 homens que conhece (só pode manter vivo o seu próprio pai...). Uma mulher evoluída pela história, emagrecida, empalidecida, cuspida, cozida, moída e remodelada a cada dia por bocas que só fazem questionar seu verdadeiro gosto. É a mulher que nunca para, porque não a deixam. Lá, na lata de lixo do fim do mundo, tem umas milhares apedrejadas. Eu, aqui, 
dilacerada. Nem a mim nem a elas resta admiração, porque resolvemos parar, e quando uma mulher que nunca para resolve parar, o mundo para de girar. Nós, as mulheres que nunca param, involuimos o coração do mundo para aumentar o seu corpo.

Samira - "É melhor JAIR se acostumando", foi o que me disseram. Mas a gente não vai se acostumar, muito menos se acovardar.

\section{A família}

(Samira toma banho em uma bacia)

Eu gosto do meu filho, gosto mesmo. Eu faço qualquer coisa por ele. O problema é que ele não parava de chorar, mesmo quando mamava. Tantas vezes eu avisei o pai dele: olha, ele está chorando! Faça alguma coisa! Mas, nada. Eu ouvia aquele choro o dia inteirinho. Para com isso, para, chega! Nunca parava. Até quando eu ficava sozinha, eu ouvia aquele choro bem miudinho, frágil... Eu estava enlouquecendo! Tive vergonha de dizer que amava o meu filho, mas não queria mais ele não. Eu queria parar, mas não me deixaram. Lembrei de todas as Medeias que eu já tinha conhecido, e decidi me dar. Dei de mamar. Pro meu filho, e pros outros que apareceram depois. A cada dia um novo menino, a cada semana uma outra menina... Meu marido me largou porque resolvi parir o mundo sozinha. Eu pari, e ele parou. Mesmo quando eu descobri que só havia leite em meu corpo, que o sangue já tinha sido todo mamado. Meus filhos imaginários pararam de chorar quando descobriram isso.

\section{Meu trabalho}

(Samira põe vestido de festa, como uma apresentadora de programa de auditório)

Boa noite plateia! Boa noite meus súditos, fãs e seguidores! Não esqueçam dos likes no insta! E me marquem nos selfs e nos stories, hein?! Diretora, faz um live do programa tá? Que plateia maravilhosa!!! Que gente linda, elegante e sincera!!!! Olha quem está aqui com a gente hoje!! (nomeia alguém da plateia, engrandece o curriculo, pede aplausos para ele). Então, vamos conhecer um pouco mais da nossa plateia. Qual é o seu nome completo? Quantos anos você tem? E quantos filhos? Como é que você vê estas pessoas que estão aqui hoje? Você confia nelas? Você já cometeu algum crime? Já furou fila? Já andou no acostamento? Já fraudou o Imposto de renda? Já carregou a filha de outra pessoa no colo para ter atendimento preferencial no banco? Já vazou áudios e imagens de outras pessoas 
na internet? Já manipulou alguma eleição? Já compartilhou fakenews? Fuma maconha? Conhece a lei antidrogas? Já foi preso? Nossa, quantas revelações, hein?! Mas hoje nossa noite será especial! Teremos um quizz, que não é o Kiss nem o Queen....É um jogo de perguntas e respostas! E quem acerta ganha um prêmio! Será uma viagem pra Cuba? Ou a garantia de participação no I Congresso de Terraplanistas? Não sabemos...Tudo vai depender da sua resposta! Então, vamos começar!

(Neste quizz, a atriz joga com o público e com as respostas, de modo que a cada acerto, tira uma peça do figurino e a dá para a pessoa "vencedora")

- qual o maior grupo étnico-racial presente nas prisões brasileiras? ${ }^{3}$

- qual o percentual de mulheres presas por tráfico de drogas no Brasil? ${ }^{4}$

- complete a frase: meninos usam azul e meninas usam...

- qual o percentual de pessoas em situação de cárcere que tem acesso à educação prisional no pais? ${ }^{5}$

- complete a frase: "a terra nunca foi redonda, ela é ....."

- você daria emprego para uma ex-detenta?

(Ruptura. Acabou o espetáculo de auditório)

Do turbilhão de perguntas com falsa pretensão, eu crio a mulher que os outros esperam: a mulher falada, e não vivida. É assim que eu tenho que caminhar. Decote não pode, coque pode. Braço, braços, braços...são sempre uma preocupação. Corta a gordura, esmaga a celulite. Torce o coração que ele vai te respeitar. Cruze as pernas. Seja forte, enterre o filho que você matou. Ame o marido que te maltratou ou nem pense em voltar pra casa. Finja. Tinja. Troque o corpo, venda a alma, tenha calma, que tudo vai se ajeitar. Espere.

\section{Dilatação do tempo-espaço}

Quando estreamos celas em 2011, tinha uma cena que eu gostava muito... se chamava "Dilatação do tempo-espaço". Para mim, essa dilatação representava diversas opressões vividas pelas mulheres: a maternidade compulsória, a tripla

${ }^{3}$ Negros (Cf.: BORGES, Juliana. Encarceramento em massa. 1a. reimpressão. São Paulo: Sueli Carneiro; Pólen, 2019).

${ }^{4}$ 62\% (Cf.: BORGES, Juliana. Encarceramento em massa. 1a. reimpressão. São Paulo: Sueli Carneiro; Pólen, 2019).

5 13\% (Cf.: BORGES, Juliana. Encarceramento em massa. 1a. reimpressão. São Paulo: Sueli Carneiro; Pólen, 2019). 
jornada de trabalho, a imagem e os padrões de beleza, o mito da mulher maravilha, a bela, recatada e do lar. Era uma cena muito física, uma dança, e isso me agradava muito. Naquela época a peça tinha um andaime de 05 metros de altura como cenário, e eu fazia cenas nos três pisos do andaime. Faz muito tempo e eu não tenho mais força pra carregar, montar e subir nesse andaime... Essa cena era no chão, no primeiro piso. No segundo piso tinha um tecido bem fino, de lycra de lingerie, no qual era projetado um texto. Como não temos mais nem andaime nem texto, eu preciso da ajuda de vocês pra fazer essa cena. Daiane, pode colocar o vídeo da cena? Não me lembro direito dos movimentos... Será que alguém poderia ler o texto pra mim enquanto eu danço?

(Samira entrega microfone para alguém da plateia ler o texto)

Mulher crime passional todos têm o direito de ir e vir e ir e vir e vir mulher Aborto assassinato tenho direito à liberdade provisória Condicional

Estupro violência doméstica

Assegura-se o direito à vida à vida ávida por vida

Matei

Roubei

Morri e fui roubada

Os homens têm direitos humanos

Só lhes falta encontrar a humanidade

Na minha idade isso já não me ocorre mais

A cidade cobre todas as bocas

Não com faixas, mas com propagandas

Aqui e ali alguém lembra que existimos

Não eu mulher não eu criança não eu adulto não eu velho não eu homem

Eu em nós

Amarrados

Amarrei e depois cortei em pedaços

Fui torturada estuprada, dilacerada

Ganho menos ganho pouco faço muito faço pouco

Quem conhece deus?

Finjo hoje minto hoje juro hoje juros hoje

Eu amante, amei, amou

Queria encontrar, mas não sabia o quê

Só olhos nos buracos, anos, ânus, cus

Impressionam pelo mistério

Assim, eu fiquei

Meio-humana, meio espectro 
Qual é a unidade doméstica?

Quem restitui os sonhos? E a inocência?

Mas ela nunca existiu

Toda pessoa tem direito a uma nacionalidade, e a minha é mulher

A mais difícil, porque nunca conheci outra

Então minha raiva, por que estamos sós

Se de nós surgiu esse mundo?

Lacremos, pois, todas as bucetas,

E quando vierem os bebês de proveta

Aprovarão

Nosso copyright.

\section{Carta de uma aluna}

Na penúltima aula de teatro com as mulheres do Presídio Regional de Joinville, na nossa cela de aula, fizemos o ensaio geral da apresentação final do curso, que seria realizada na aula seguinte. Depois, pedimos pra elas escreverem uma carta para alguém que elas quisessem muito que lesse. Essas cartas estão aqui conosco hoje, e nós gostaríamos de compartilhá-las com vocês, para que os sonhos e os desejos de futuro dessas mulheres não fiquem trancafiados atrás das grades.

"Morava em uma ruazinha estreita na beira do trilho, do bairro humilde chamado Itaum. Quando criança passei muita necessidade, a ponto de ter que pedir esmolas e por várias vezes levar 'não' na cara. Sempre fui uma menina do 'bem'. Participava da missa aos domingos na Igreja São Judas Tadeu. Não tínhamos água encanada e eu, como irmã mais velha, ficava na função de buscar água do poço. E lá eu ia com os baldes cheios d'água para dentro de casa. Na adolescência tinha vontade de sair com as amiguinhas nos bailinhos, mas meu pai era rude e limitava o horário, pois queria que suas filhas fossem 'belas, recatadas e do lar'. Ano vai ano vem e me apaixonei pelo pai dos meus filhos. Eu tinha apenas 13 anos de idade - uma menina. Passaram-se dois anos e engravidei da minha primeira filha. Minha barriga ficou linda! Meu pai, no início, não queria me aceitar, mas com o tempo tudo deu certo. Permanecemos casados durante 23 anos, entre altos e baixos. Eu, como sempre, era uma mulher apaixonada e dedicada na função de mãe e esposa. A vida estava bem, mas o que eu não gostava é que ele usava drogas, e ele usava com frequência. E esse foi o motivo que fez com que nós nos separássemos. Nesse meio tempo eu fui presa por tráfico de drogas e na prisão fui abandonada por ele e por meus filhos também. Foi onde decidi permanecer sozinha, pagar minha condenação e quem sabe lá na frente dar uma oportunidade para a minha vida. Foi quando eu menos esperava, por estar dentro da prisão, que conheci o M. 
Um homem maravilhoso, que me assumiu e hoje assumiu os meus filhos. Um companheiro exemplar, nunca me abandonou, em nenhum momento. Aqui dentro do sistema o que dói mais são as saudades. Aqui é um lugar como 'esses' onde somos frutos de tormento, tristezas, frustrações, dentro dessas celas frias onde somos obrigadas a conviver dia-a-dia com várias personalidades, com pessoas que nunca vimos na vida, enfim obrigatoriamente somos vítimas de muita tristeza e dor. A dor da saudade é a que mais tortura a presa. Depois de três anos presa tive a oportunidade de participar de um grupo teatral que frequento todas as sextas-feiras, onde me distraio. Mas confesso que bate um desânimo enorme. Tento buscar forças e energias boas nas professoras que vêm de fora, que se unem para nos trazer alegria e junto com o Juiz nos beneficiar com a remissão. 0 que mais indigna a presa é o fato dos comentários dos ministros e governantes de que existe um custo grande para cada presa, sendo que não temos o direito nem a um trabalho, nem ao estudo. Estamos no século XXI, e nós mulheres somos bem esquecidas e desvalorizadas no sistema prisional. Afinal somos mulheres e necessitamos de regeneração para retornar a nossa vida lá fora para com os nossos familiares. Na maioria das vezes nos tornamos reincidentes por não termos oportunidades e ao sair da prisão nos deparamos com um mundo onde tudo é tentação e nós sem o maldito dinheiro, não somos nada nessa vida. Fico pensando se as autoridades sabem que tudo é uma barbárie, uma catástrofe e que isto sai muito caro. Eu me pergunto: Por que eles prendem miseráveis? Vejo casos que me enlouquecem, pois governadores, parlamentares, são presos por bilhões e são em seguida, beneficiados, enquanto eu com 03 gramas de crack fui sentenciada há sete anos e nove meses de prisão. Estou presa há três anos e tenho que pagar quatro anos e oito meses para alcançar algum benefício, por esses motivos eu me pergunto: Por que não refletem sobre os motivos das mulheres se envolverem com o crime? Por que este aumento brutal de mulheres presas, sendo que a maiorias fez pelos filhos, pelo marido, por amor? Por que os Juízes pouco aplicam as penas alternativas e muito menos as medidas cautelares que não a prisão? Por que não se pensa que a prisão rompe as relações familiares e traz consequências danosas para os filhos das presas? Por que o indulto natalino nunca beneficia as mulheres? Quero uma coisa, que olhem para mim! Para mim e para todas as mulheres que estão na prisão... na minha situação, 'querer não é poder', mas o que eu sinto no meu coração e falo em nome de todas as presas do sistema prisional de Joinville é que jamais devemos esquecer que existe um Deus, e onde há esperança, essa permanecerá para sempre." 


\section{Urdimento}

[celas] e elas

Recebido em: 23/11/2020

Aprovado em: 26/11/2020

Universidade do Estado de Santa Catarina - UDESC

Programa de Pós-Graduação em Teatro - PPGT

Centro de Arte - CEART

Urdimento - Revista de Estudos em Artes Cênicas

$\underline{\text { Urdimento.ceart@udesc.br }}$ 